\title{
Mapping Human Rights to Democratic Policing Through the ECHR
}

\author{
Andy Aydın-Aitchison \\ Senior Lecturer in Criminology, University of Edinburgh School of Law \\ Edinburgh, United Kingdom \\ andy.aydin-aitchison@ed.ac.uk
}

Ceren Mermutluoğlu

Research Assistant, MEF University Faculty of Law, Istanbul, Turkey

Doctoral Candidate, Galatasaray University, Istanbul, Turkey

mermutluogluc@mef.edu.tr

\begin{abstract}
This article examines how human rights relate to democratic policing. We differentiate policing for democracy, which protects democracy, from democratically responsive policing, where police are governed democratically. Using this two-fold distinction to examine European Court of Human Rights cases, we find a close match between Convention rights and policing for democracy. Regarding democratically responsive policing, the Court provides responsiveness within the structural limits of reacting to individual complaints, and as one element in the broader landscape of governance. Further, cases show how that landscape features in Court judgments. We argue that robust enforcement, and careful attention to case law during drafting and implementation of police legislation and governance arrangements, help protect democracy and enhance democratically responsive policing.
\end{abstract}

\section{Keywords}

police - democracy - ECHR - responsiveness - human rights 
The relationship between democratic policing and democratic government has been described as 'symbiotic.' Likewise, human rights and democracy are often explored in terms of their inter-relatedness. ${ }^{2}$ It follows that democratic policing and human rights are related, and indeed they are often spoken about in proximity. The Organisation for Security and Co-operation in Europe sees the protection of human rights as one dimension of democratic policing. ${ }^{3}$ Democracy and human rights appear together in the preamble to the Patten Report on policing in Northern Ireland, and the Commission's tests of police reform proposals amount to five common indicators of democratic policing and one of human rights. ${ }^{4}$ Kartay and colleagues include police attitudes to human rights as one variable when assessing democratic policing in Turkey. ${ }^{5}$ Jones and colleagues do not explicitly reference human rights among criteria of democratic policing in their foundational contribution, yet elsewhere, Engels and Burruss use the same criteria to demonstrate policing which adheres to human rights standards. ${ }^{6}$ The mutual interdependence of rights and democracy features in Neyroud and Beckley's analysis of police ethics. ${ }^{7} \mathrm{~A}$ threeway nexus between policing, democracy and human rights is most evident in

1 R. Neild, 'Democratic Police Reform in War Torn Societies', Conflict, Security and Development, 2001, vol. 1, no. 1, pp. 21-43. DoI: 10.1080/14678800100590596. For one of the earliest statements on the relationship, see also D. Bayley, The Police and Political Development in India, Princeton University Press, Princeton NJ, 1969.

2 J. Dryzek, 'Can there be a Human Right to an Essentially Contested Concept? The Case of Democracy', The Journal of Politics, 2016, vol. 78, no. 2, pp. 357-367. DoI: 10.1086/684585.

3 OSCE Guidebook on Democratic Policing, 2008, $2^{\text {nd }}$ edition, Vienna, osce, p. 9. See also D. Bayley, Changing the Guard:Developing Democratic Police Abroad, Oxford: Oxford University Press, 2006, p 19; B. Goold, 'Policing and Human Rights' in B. Bradford, B. Jauregui, I. Loader and J. Steinberg (eds) Sage Handbook of Global Policing, London: Sage, 2017, pp. 226-240, at p. 232; J. Hornberger, 'Human Rights and Policing: Exigency and Incongruence', Annual Review of Law and Social Science, 6, pp. 259-283, at p. 267. DoI: 1550-3585/10/1201-0259.

4 A New Beginning: Policing in Northern Ireland-The Report of the Independent Commission on Policing for Northern Ireland, 1999. Retrieved 30 May 2016, http://www.cain.ulst.ac.uk/issues/ police/patten/patten99.pdf.

5 A. Kartay, M. Wiatrowski, J. Vardalis and K. Bowen, 'An Assessment of Democratic Policing in Turkey', International Journal of Police Science and Management, 2012, vol. 14, no. 4, pp. 299311. DOI: 10.1350/ijps.2012.14.4.291.

6 S. Engel and G Burruss, 'Human rights in the new training curriculum of the Police Service of Northern Ireland', Policing: an International Journal of Police Strategies and Management, 2004, vol. 27, no. 4, pp. 498-511. DoI: 10.1108/13639510410566244. For the criteria and the underlying concept of democracy, see T. Jones, T. Newburn and D. Smith, Democracy and Policing, 1994, London, Policy Studies Institute, pp. 36-48.

7 P. Neyroud and A. Beckley, Policing, Ethics and Human Rights, 2001, Cullompton, Willan, p. 60. 
Kutnjak-Ivković and Borovec's study of Croatia which, while not using case law, identifies the most relevant rights in the European Convention on Human Rights (ECHR). ${ }^{8}$

This paper goes further in examining the overlap between democratic policing and human rights. Firstly, it uses a conceptual distinction from criminology between policing which protects and sustains democracy (policing for democracy) and policing directed and governed in line with specific democratic principles (democratically responsive policing). ${ }^{9}$ Secondly, it integrates a wider set of Convention rights than those included by Kutnjak-Ivković and Borovec. Thirdly, it uses the conceptual frame to interrogate relevant cases decided at the European Court of Human Rights (ECtHR) identified through the HUDOC database. ${ }^{10}$ Examining the relevant articles and principles of the $\mathrm{ECHR}^{11}$ in light of a distinction between policing for democracy and democratically responsive policing reinforces the value of separating out these two dimensions and the mapping exercise produces a fine-grained understanding of how human rights frameworks relate to democratic policing. We show a close match between policing in line with human rights obligations and policing for democracy, particularly in relation to Articles 2 and 3 (life, and prohibition on torture, inhuman and degrading treatment); 5 (liberty and security), and more explicitly 'political' rights covered in articles 8 through 11 and Protocol 1.3. On the other hand the needs of democratically responsive policing are only partially met by policing in the framework of the ECHR, as may be anticipated from literature on police governance. Nonetheless, the Court currently facilitates responsiveness to citizens, especially as a mechanism of redress, and in important ways supports a system of police responsiveness to other institutions. Here, while specific articles are of note (particularly 5,6 and 13), it is the more general function of the Court that cements its place in a democratically responsive framework of police governance. Ultimately, we propose that careful attention to Convention rights and principles during drafting and implementation of legislation, and robust enforcement of the convention, enhance both forms of democratic policing.

8 S. Kutnjak-Ivković and K. Borovec, 'Protecting Human Rights: a Complex Story of the Democratisation of the Croatian Police', International Journal of Comparative and Applied Criminal Justice, 2018, vol. 42, no. 1, pp. 1-31, at p. 6. DOI: 10.1080/01924036.2016.1270841. A. Aitchison and J. Blaustein, 'Policing for Democracy or Democratically Responsive Policing? Examining the Limits of Externally Driven Police Reform', European Journal of Criminology, 2013, vol. 10, no. 4, pp. 496-511. Dor: 10.1177/1477370812470780.

$10 \mathrm{https} / /$ www.echr.coe.int/Pages/home.aspx?p=caselaw/HUDOC\&c=.

11 ECHR is taken as a firmly institutionalised framework for Human Rights which covers 47 of the 57 OSCE member states. 
As Human Rights focuses largely on states, ${ }^{12}$ we only examine public police agencies. While the work is focused on Europe and at the level of ECtHR, similar issues are evident elsewhere, and the analysis could be extended outwards to review police in other states, ${ }^{13}$ or inwards to examine domestic decisions on Convention rights. ${ }^{14}$ In the following we elaborate on the distinction between the two concepts of democratic policing and outline our approach before taking each form of democratic policing in turn, examining how they are served and illustrated by ECtHR judgments.

\section{Democratic Policing}

When separating policing which supports political democracy from policing which is democratically responsive, Aitchison and Blaustein were concerned about overly-powerful external influences driving policing in a small, fragile state. ${ }^{15}$ External intervention can help protect an emerging democracy, but can also skew the locus of policing decisions away from domestic constituencies. In spite of the focus on emerging democracies, the distinction is analytically useful in established democracies, and can be applied to the diverse states that have signed or ratified the ECHR. The concept of democracy employed is one which goes beyond procedural dimensions to incorporate the capacity for public debate of policy alternatives. ${ }^{16}$

Policing for democracy recognises police forces need not be democratically governed to support core elements of democratic government. The focus is largely on police actions and behaviour. This means restraining from intimidating acts or the use of oppressive force, and acting in ways in which personal

12 S. Burbidge, 'The Governance Deficit: Reflections on the Future of Public and Private Policing in Canada', Canadian Journal of Criminology and Criminal Justice, 2005, vol. 47, no. 1, pp. 63-86. Dor: 10.3138/cjccj.47.1.63.

13 M. Marks and J. Wood, 'South African Police at a Cross Roads: the Case for a 'Minimal' and 'Minimalist' public police', Theoretical Criminology, 2010, vol. 14, no. 3, pp. 311-329. DoI: 10.1177/1362480610369785; Sampson, I.T. 'The Right to Demonstrate in a Democracy: an Evaluation of Public Order Policing', African Human Rights Law Journal, 2010, vol. 10, no. 2, pp. $43^{2-56}$. With adaptions to account for different frameworks, procedures and contexts, the approach we take here could be applied to domestic jurisdictions with their own or international rights instruments, or to other international venues such as the African Court on Human and People's Rights or the Inter-American Court of Human Rights.

14 We return to our rationale for focusing on ECtHR in discussing methods, below.

15 Aitchison and Blaustein, 'Policing for Democracy or Democratically Responsive Policing?' p. 497.

$16 \quad$ Ibid. p. 498. 
political views and commitments do not shape professional practice. It also entails a range of positive obligations to protect the functioning of constitutional bodies, electoral processes and the surrounding free public dialogue. The effective and equitable provision of a secure space in which free political action and communication can take place constitutes policing for a democracy. ${ }^{17}$

Democratically responsive policing is wider and focuses on the mechanisms and structures surrounding police policy and action. As will be seen in the analysis, this can go beyond the police to include, for example, prosecutorial and judicial bodies. This makes it more accurate to talk of democratically responsive police systems, recognising that the borders of 'policing' go beyond just the 'police'. Although overlooked in Aitchison and Blaustein's work on police and democracy, the idea of a police system is well-established in the policing literature, ${ }^{18}$ and helps to locate police action in relation to the processes and actors that play a role in shaping it. Following Kuper, Aitchison and Blaustein focused on democratic police governance as characterised by responsiveness. ${ }^{19}$ This demands that policing is shaped in response both to the population of a polity (vertical responsiveness) and to other institutions (horizontal responsiveness). Commonly identified features of democratic policing feed into structures which demand police respond to citizens and to legal and political institutions. These features speak to vertical aspects (redress, participation, reaction, accessibility), horizontal aspects (competition, distribution of power, accountability) or both (information). Vertical forms of responses refer to a more direct means by which citizens can signal their interests to the state, whereas horizontal responsiveness defines an institutional arrangement that favours different authorities in a relationship requiring compromise and consensus building to maximise the system's responsiveness "to the views and best interests of the public."20 This responds to the epistemic impossibility of a single perspective representing 'perfect knowledge' or the 'totality of political knowledge.'21 As such, Kuper proposes multiple authorities dependent on each other to fulfil their functions ${ }^{22}$ and presenting each other with "an ongoing and credible threat of exposure and sanction." ${ }^{23}$ Aitchison and Blaustein, following

17 Ibid. p. 499.

18 R.I. Mawby, 'Models of Policing' in T. Newburn (ed.) Handbook of Policing, Cullompton: Willan, pp. $15-40$, at 15 .

19 Ibid. pp. 500-502, drawing on A. Kuper, Democracy beyond Borders:Justice and Representation in Global Institutions, 2004, Oxford, Oxford University Press.

$20 \quad$ Kuper, Democracy beyond Borders, p. 78.

21 Ibid.pp. 115-116.

$22 \quad$ Ibid. p. 103.

23 Ibid.pp. 107 and 102-104. 
Loader and Walker, qualify 'response' to include a reasoned rejection of citizens' wishes. ${ }^{24}$ Not all features are addressed here. For example, the dimension of competition is specific to contexts where police compete against other, often private, service providers which goes beyond the scope of the paper. Further, the wider landscape of police governance, and elements of democratic responsiveness that relate less to the individualised focus of a human rights court are not addressed in detail. ${ }^{25}$ We do not argue that the Convention and Court provide an exhaustive account of democratically responsive police. Rather, they highlight important mechanisms in a landscape of governance which support responsiveness, and the Court serves as one such mechanism in its own right.

\section{$3 \quad$ Methods}

In the following sections, we link convention rights and case law to the two dimensions of democratic policing. This was done through a two-stage process. First, based on our reading of the literature on democratic policing, we undertook a process of conceptual mapping, identifying likely linkages between the two forms of democratic policing and the articles of the ECHR. Second, we undertook a review of case law in which police or police systems play a key role. The review utilised the HUDOC database, and proceeded on an article by article basis where we had a credible conceptual basis for linking the right to democratic policing. We focused only on cases rated as 'key' or 'high importance' in the database, ${ }^{26}$ and used text searches to find those relating to

24 Aitchison and Blaustein, 'Policing for Democracy or Democratically Responsive Policing?' p 500; Loader and Walker, Civilizing Security, pp. 227 ff. See also Kuper, Democracy beyond Borders, p 104.

25 A. Malik, 'Police Governance and Accountability in Scotland Following Reform: Revisiting the Policy Rationale for the Creation of the Scottish Police Authority', Scottish Affairs, 2019, vol. 27, no. 4, pp. 438-464, Dor: 10.3366/scot.2018.0257. Malik gives a detailed examination and critique of the Scottish Police Authority as one such generalised oversight mechanism whose remit operates above the level of the individual. For an account of a local forum for participation, and theorisation of its limits, see D. Harkin, 'Simmel, the police form and the limits of democratic policing' British Journal of Criminology, 2015, Vol 55, no. 4, pp. 730-746. DOI: $10.1093 / \mathrm{bjc} /$ azvo18.

26 Key cases are selected by the Bureau of the Court (i.e. the President, Vice-Presidents and Section Presidents) on the proposal of the Jurisconsult, based within the Court Registry, and reflect the cases deemed most important. See e.g. ECtHR, Key Cases 2019, https:// www.echr.coe.int/Documents/Cases_list_2019_ENG.pdf. Prior to proposal and selection, cases are given a provisional ranking, with 1 indicating cases of 'high importance' which make a "significant contribution to the development or modification [of the Court's] case law, either generally or in relation to a particular state", see information note ('?') to the 
police before more detailed reading. ${ }^{27}$ Rather than producing a classic doctrinal approach to the case law, we offer a review of cases and underlying rights informed by the conceptual literature on democratic policing which is largely, though not exclusively, located in criminological scholarship as highlighted in the previous two sections. Applying this framework to the Court's outputs draws validity from two factors. First while the Convention is applied domestically in many states, the Court enjoys particular authority in its interpretation of rights ${ }^{28}$; and secondly the active participation of the Court in a landscape of police governance. The Court thus contributes both conceptually and empirically to the space of interest at the intersection of human rights and democratic policing.

\section{Policing for Democracy 1: Equitable, Effective Security of Person (Articles 2 and 3)}

If part of securing democracy is providing basic security to citizens, allowing them to pursue lawful activities including, but not limited to, a range of democratic rights linked to open public debate (free speech, free assembly), then a state force that kills or physically attacks citizens is acting in an anti-democratic way. This is the case regardless of whether such action is targeted or arbitrary, but selectively targeted violence brings in a new dimension of anti-democratic policing by closing down specific forms of oppositional political activity. In terms of the ECHR, the key articles here are Article 2 (right to life) and Article 3 (freedom from torture and inhuman or degrading treatment), alongside Article 14 (non-discrimination). Equally, a state failing to protect citizens,

'Importance' heading at the database, https://hudoc.echr.coe.int/eng\#\{\%22documentcol lectionid $2 \% 22:[\% 22$ GRANDCHAMBER\%22,\%22CHAMBER\%22]\}.

27 Our cases cover 24 different state parties and judgments rendered between 1988 and 2019. The account is not specific to one period or national jurisdiction, and favours conceptual mapping over context-specific coherence at this stage. We did not adopt a chronological approach in our analysis, but as a further step, it would be possible to analyse the evolution of the Court's position in relation to human rights, democracy and police.

28 A. Ashworth and M. Redmayne, The Criminal Process, $4^{\text {th }}$ edition, 2010, at 29; M. O'Boyle, 'The Future of the European Court of Human Rights', German Law Journal 2011, vol. 12, no 10, pp. 1862-1878, at 1868; this authority, and related legitimacy, is not unqualified, and maintaining this authority can shape decision making, as examined in F. de Londras, 'Dual functionality and the persistent frailty of the European Court of Human Rights', European Human Rights Law Review, 2013, no. 1, pp. 38-46; F. de Londras and K. Dzehtsiarou, 'Managing Judicial Innovation in the European Court of Human Rights', Human Rights Law Review, vol. 15, no. 3, pp. 523-547. 
and to give all citizens equal protection, is, if not anti-democratic, at least failing as a democracy. While Articles 2 and 3 are non-derogable and are to be interpreted independently of their relationship to democracy, ${ }^{29}$ we are arguing that they are fundamental to policing for democracy.

\subsection{Life and Integrity: Restraint}

In cases handling Articles 2 and 3 featuring absences of restraint by police, we examine three forms of anti-democratic policing: direct killings; non-lethal violence against marginalised or excluded groups; and non-lethal violence towards formal, informal or perceived sources of opposition to state authorities. Many cases handling alleged substantive breaches of the right to life by state police concern deaths, abductions and disappearances in the North Caucasus region of the Russian Federation. ${ }^{30}$ These cases are extreme in terms of frequency, the unsettled contexts in which they occur, the intent of state actors, and the state's lack of convincing explanation for events that evidently involve state functionaries. There is little merit in analysing them further. Rather, like the Court in Dalakov, we reiterate that the right to life is a fundamental value in democratic societies ${ }^{31}$ and these are fundamentally anti-democratic acts.

Two further cases of killing by state police arise in the specific context of protests. These are significant for the unwarranted loss of life and in terms of the possible effect on freedom of assembly (Article 11). In both Nagmetovv Russia and Ataykaya v Turkey, tear gas canisters fatally struck the applicants' sons during protests. ${ }^{32}$ In the former, the Russian government accepted that the manner in which the officer fired the weapon was in breach of domestic law, while in the latter, where the victim was a bystander rather than a protestor, the Turkish government argued that the use of weapons was legally mandated. ${ }^{33}$ The lack of legal provisions, and corresponding training, ensuring appropriate use of weapons in a non-lethal manner (i.e. firing at a high angle rather than along a horizontal trajectory), amounted to a failing of the state to meet positive obligations under Article $2 .{ }^{34}$

\footnotetext{
29 Ashworth and Redmayne, Criminal Process, at 37 and 48.

30 Chechen Republic and the Republics of Dagestan, Ingushetia and North Ossetia-Alania. See, e.g. Nazyrova and Others $v$ Russia, ECtHR, 21126/og, 63620/og, 64811/og, 32965/10 and 64270/11, 9 February 2016; Aliyev and Gadzhiyeva v Russia, ECtHR, 11059/12, 12 July 2016; Gaysanova $v$ Russia, ECtHR, 62235/o9, 12 May 2016 among others.

31 Dalakov v Russia, ECtHR, 35152/o9, 16 February 2016, para. 61.

32 Nagmetov v Russia, ECtHR 35589/o8, 30 March 2017; Ataykaya v Turkey, ECtHR 50275/o8, 22 July 2014.

33 Ataykaya $v$ Turkey, para. 42.

34 Ibid, paras $57-58$.
} 
Ciorcan and others $v$ Romania, brought by 37 Roma residents of Reghin, examines potentially lethal police violence. The case concerns police action against a minority group widely recognised as marginalised and excluded from the public sphere across Europe. ${ }^{35}$ We return to the broader issue of marginalisation in discussing dignity, below. Local and special police forces deployed to serve a summons on two Roma men after an initial complaint from a local officer concerning insulting behaviour. The manner of deployment did not fit with any reasonable anticipation of resistance and officers used disproportionate force, including firing live ammunition towards a crowd. ${ }^{36}$ The Court found a substantive breach of Article 2, but owing to a lack of concrete evidence, arising from state failures in conducting a full investigation, did not find a substantive breach of Article 3. In the matter of discrimination (Article 14), the Court criticised the intervention, but found insufficient grounds to conclude racist motive for state agents' actions. ${ }^{37}$ In part, this resulted from inadequate investigation of the events by the state party, which itself forms the basis for an Article 14 violation. ${ }^{38}$ This highlights an issue with rights protection mechanisms: They are only as good as the evidence-gathering that supports findings. Where these are in the hands of those being scrutinised, any systemic racism underpinning a breach of rights would logically obstruct the investigation of racism as the reasons for that breach. ${ }^{39}$

35 Ciorcan and others $v$ Romania, ECtHR, 29414/og and 44841/og, 27 January 2015, revised 17 January 2017. On marginalisation see, for example, L.L. Herakova, 'Identity, Community, Inclusion: the Roma and (New) Europe', Journal of International and Intercultural Communication, 2009, vol. 2, no. 4, pp. 279-297. Dor: 10.1080/17513050903177318; J. Škrijel, 'Common Obstacles towards Democracy: the Protection of Roma Rights in Romania and Macedonia', Ресов's Volumes, 2014/15, Bologna, РЕСов, pp. 17-35.

36 Ciorcan and others $v$ Romania, para 111 , in para 156 the deployment was described as 'grossly excessive'. Elsewhere under the heading of Article 3 the importance of a robust operational planning process is identified, see e.g. Rehbock $v$ Slovenia, ECtHR 24692/95, 28 November 200o, para. 72 and Gutsanoviv Bulgaria, ECtHR 34529/10, 15 October 2013, paras 131-133, 136-137.

$37 \quad$ Ibid, para. 163.

$38 \quad$ Ibid, paras 164-167.

39 Also, in Bekos and Koutropoulos v Greece, ECtHR 15250/02, 13 December 2005, The same issue is evident in that there was insufficient evidence for the Court to find a substantive violation of Article 14, but this stemmed from failures to investigate a racist motivation for police abuse of two Roma men, itself the basis for a procedural Article 14 violation. At the time of writing, the Court had just released its judgment in Lingurar $v$ Romania, ECtHR 48474/14, 16 April 2019. In this case, the judgment found two Article 14 violations in addition to an Article 3 violation arising from injuries inflicted on members of a Roma family during a raid by gendarmes. Here the Court was able to find evidence of discrimination in the form of ethnic profiling which resulted in the disproportionate deployment and use of force in the initial raid, and in the Romanian prosecutor and court's dismissal of the 
Police violence against political opposition is evident in Virabyan $v$ Armenia, in which an opposition party member involved in Presidential elections was detained and seriously assaulted. ${ }^{40}$ The degree of the assault, and the inference that it was carried out to punish or intimidate the applicant, supported a finding of torture, breaching Article $3{ }^{41}$ Considering this breach alongside Article 14 on non-discrimination, the Court outlines part of the rationale for the oft repeated claim ${ }^{42}$ that Article 3 represents a fundamental value of democratic societies and the need for police, as state agents, to respect it:

Political pluralism, which implies a peaceful co-existence of a diversity of political opinions and movements, is of particular importance for the survival of a democratic society based on the rule of law, and acts of violence committed by agents of the State which are intended to suppress, eliminate or discourage political dissent or to punish those who hold or voice a dissenting political opinion pose a special threat to the ideals and values of such society. ${ }^{43}$

The case again highlights a limit of the Court as a rights protection mechanism. In the same way that it was unable to determine a racist motivation for police actions in Ciorcan, it could not objectively verify evidence that would provide a firm basis to conclude that the assault in Virabyan was rooted in political discrimination. ${ }^{44}$ Again, systems for providing and verifying evidence were lacking in the state under scrutiny. The breaches described so far give a good account of different aspects of anti-democratic policing.

\subsection{Life and Integrity: Positive Obligations}

Beyond protecting individuals from direct harm at the hands of state agents, Articles 2 and 3 carry positive obligations for states to protect the lives and physical safety of those within their jurisdiction. Following on from the discussion of Ciorcan above, Opuz v Turkey handles state responses to threats to the

applicants' complaints (paras 74-82). For a summary of the development of case law on dealing with bias motives, see EU Agency for Fundamental Rights, Unmasking Bias Motives in Crimes: Selected Cases of the European Court of Human Rights, 2018. URL: https:// fra.europa.eu/sites/default/files/fra_uploads/fra-2018-unmasking-bias-motivespaper_en.pdf

$40 \quad$ Virabyan v Armenia, ECtHR, 40094/05, 2 January 2013.

$41 \quad$ Ibid, para. 157.

$42 \quad$ Ibid, para. 148.

43 Ibid, para. 200.

44 Ibid, para. 214. 
life and safety of members of a systematically disadvantaged group. It outlines a series of assaults and threats, over an extended period, against the applicant and her mother on the part of the former's husband, culminating in the murder of the applicant's mother. ${ }^{45}$ Domestic violence is disproportionately targeted at women, and is an entrenched problem which reinforces a weaker social position and compounds other factors leading to marginalisation and exclusion from the public sphere. In $\mathrm{Opuz}$, fault was found with a legal framework misaligned with "the status of women in a democratic and pluralistic society", with judicial passivity, the specific police treatment of the applicant and her mother, and a general approach prioritising mediation over investigation. ${ }^{46}$ Likewise, the failure to investigate appropriately crimes of violence against Roma individuals are highlighted in Šečić v Croatia and Škorjanec $v$ Croatia. ${ }^{47}$ Here, racially motivated crimes of violence are singled out as requiring special treatment in the investigative phase as they are especially destructive of fundamental rights. ${ }^{48}$ The underlying logic is outlined in Nachova and Others $v$ Bulgaria, and as with Opuz, the emphasis is on pluralism, here expressed as the place of diversity in democratic societies:

... the authorities must use all available means to combat racism and racist violence, thereby reinforcing democracy's vision of a society in which diversity is not perceived as a threat but as a source of enrichment. ${ }^{49}$

Such cases show the obligation on states to take action which deters violence both in the specific sense of serial violence against an individual and in the general sense of violence targeting groups on the basis of identity.

The conflict in the South East of Turkey provides the context for a number of cases dealing with the protection of life, several of which relate to victims in political roles (broadly defined) antagonistic to state objectives. This includes

45 Opuz v Turkey, ECtHR, 33401/o2, 9 June 2009, for the account of events accepted by the Court, see para. 133 i-viii.

46 Ibid, paras 192-195. Italics added. Other examples of a failure to protect individuals from socially marginalised categories include the failure to prevent recurring harassment of a man with physical and developmental disabilities in Đordević v Croatia, ECtHR, 41526/10, 24 July 2012.

47 Šečić v Croatia, ECtHR, 40116/02, 31 May 2007; Škorjanec v Croatia, ECtHR, 25536/14, 28 March 2017.

48 Šečić, para. 67 ; Škorjanec, para. 53.

49 Nachova and Others $v$ Bulgaria, ECtHR, 43577/98, 43579/98, 6 July 2005, para. 145, italics added. 
newspaper vendors, ${ }^{50}$ journalists, ${ }^{51}$ members in political parties representing Kurdish interests, ${ }^{52}$ and union activists. ${ }^{53}$ While cases vary, they share a common feature of police authorities failing to act in light of threats to individuals, following which those individuals were killed. ${ }^{54}$ In the case of Hüseyin Koku, he was abducted by men apparently acting as plain clothes police officers, although the police denied having taken him into custody. Subsequently, his family reported to the authorities receiving a telephone call in which Hüseyin could be heard being tortured, but no official action was initiated for two and a half months. Six months after the abduction his decomposed and dismembered body was discovered. ${ }^{55}$ In the cases of $A k k o c ̧$ and Kilıç (respectively a trade unionist and a journalist), threats were reported to the authorities which the Court found to be indicative, of a "particular, real and immediate risk". ${ }^{6}$ In both cases, these reports were followed by a lack of investigative and preventive action ${ }^{57}$ and both Zübeyir Akkoç and Kemal Kılıç were shot dead while travelling between work and home. The lack of state action is situated in a context in of killings of opposition figures. A parliamentary report had detailed concerns over state security forces supporting or acquiescing in non-state actors' killing of those "perceived to be acting against state interests". ${ }^{58}$ Whether one assumes direct state involvement, a looser sense of acquiescence, or simply selective indifference towards the targeting of political opponents, it is clear that the resulting ineffective and iniquitous policing is a fundamental threat to participation in democratic politics, both in terms of the specific individuals killed and more generally by discouraging participation through fear of consequences. These cases indicate failures to act on credible information regarding threats, and can be taken as examples of the kinds of 'well-defined

5o Yaşa v Turkey, ECtHR, 63/1997/847/1054, 2 September 1998. This case found only a breach in the investigative arm and is not further discussed here.

$5^{1}$ Kılıç $v$ Turkey, ECtHR, 22492/93, 28 March 2000. Similarly, although not in relation to the South East, but more generally in relation to Turkey's minority Armenian population, see Dink v Turkey, ECtHR, 2668/07, 6102/o8, 30079/o8, 7072/o9 \& 7124/o9, 14 September 2010 (French).

$5^{2} \quad$ Kokuv Turkey, ECtHR, 27305/95, 31 August 2005.

53 Akkoçv Turkey, ECtHR, 22947/93 and 22948/93, 10 October 2000.

54 In the later case of Dinkv Turkey, ECtHR, 2668/07, 6102/08, 30079/08, 7072/09 and 7124/o9, 14 October 2010, combining an Article 2 and Article 10 violation, the Court is explicit in connecting the positive obligation of protection falling on the state with the participation of all persons concerned in public debates (la participation aux débats publics de toutes les personnes concernées), para. 137.

$55 \quad$ Kokuv Turkey, paras 19, 32 and 131-143.

56 Akkoç, para. 81; similar phrasing is used in Kılıç, para. 66.

$57 \quad$ Akkoç, para. 82; Kılıç, para. 76.

$5^{8} \quad$ Akkoç, paras 83-84; Kılıç, para. 68. 
circumstances' which generate an obligation on the state to undertake preventive operations to protect individuals. That obligation is not unlimited. The Court recognises that unpredictability and finite resources are important contextual factors in setting out the likely circumstances in which the obligation stands. ${ }^{59}$

\subsection{Dignity, Communicative Action and Belonging}

Beyond this, Article 3 cases show police undermining individual dignity in ways which are anti-democratic. Ian Loader's writings on police, security and politics often return to themes around the symbolic power exercised by police. ${ }^{60}$ Particularly, he writes that:

... policing is a social institution whose routine ordering and cultural work communicates authoritative meanings to individuals and groups about whether their voices are heard and claims recognised about where and in what ways they belong. ${ }^{61}$

And again he states that police 'talk and action' send 'signals about whose voices are to be heard or silenced.' ${ }^{2}$ The case law of the Court shows police action seriously infringing on individuals' dignity. This need not involve physical violence as is evident in the humiliation and debasement deliberately inflicted on an applicant exposed in handcuffs at home and at his workplace. ${ }^{63}$ Cases featuring physical violence also show other forms of humiliation. In Menesheva, the applicant, having been beaten and detained, was forced to wash the police station floor before being released. ${ }^{64}$ Cases of violence as an infringement of dignity range from a slap, ${ }^{65}$ through serious beating and electrocution, ${ }^{66}$ to

59 For example, see Osman $v$ The United Kingdom, ECtHR, 23452/94, 28 October 1998, paras $115^{-116 .}$

6o I. Loader, 'Policing, Recognition and Belonging', Annals of the American Academy of Political and Social Science, 2006, no. 605, pp. 202-21. Dor: 10.1177/0002716206286723; I. Loader and A. Mulcahy, Policing and the Condition of England: Memory, Politics and Culture, 2003, Clarendon, Oxford; I. Loader and N. Walker, Civilizing Security, 2007, Cambridge, Cambridge University Press.

61 Loader, 'Policing, Recognition and Belonging', p. 203.

$62 \quad$ Ibid, p. 211.

63 Erdoğan Yağızv Turkey, ECtHR, 27473/02, 6 March 2007, para. 47.

64 Menesheva v Russia, ECtHR, 59261/oo, 9 March 2006, para. 21.

65 Bouyid v Belgium, ECtHR, 23380/o9, 28 September 2015; Balogh v Hungary, 47940/99, 20 October 2004.

66 Nechiporuk and Yonkalov Ukraine, ECtHR, 4231/04, 21 April 2011. 
rape. ${ }^{67}$ These police acts are communicative. Among other messages, they convey that those at the receiving end, whether as individuals or as members of social groups or categories, are subject to police or state power while they themselves are disempowered. In a number of cases, the individuals are from groups that are already experiencing other forms of social marginalisation or disadvantage related to ethnicity, gender or class, and such attacks on dignity may compound this. The Court has noted how this contributes to feelings of arbitrariness, injustice and powerlessness. ${ }^{68}$

\section{5}

Policing for Democracy 2: Liberty (Article 5)

The key purpose of Article 5 is to prevent arbitrary or unjustified deprivations of liberty. The right not to be detained other than under defined lawful circumstances (Article 5.1, a-f) is given the highest priority as a feature of democratic societies, although again as a 'strong' right its interpretation and application is not limited by democracy. ${ }^{69}$ Recognising principles of operational independence $^{70}$ and discretion, the Court makes allowances for the fact that police decision making is complicated and is often based on factors not readily knowable to others. ${ }^{71}$ Included in these decision-making processes may be a need to protect the convention rights of others, including the right to life. ${ }^{72}$ With this in mind, while there is an initial requirement of lawfulness at the point of detention, key procedural rights kick in after a decision on detention in order to provide a retrospective check against arbitrariness and speak largely to issues around responsiveness explored later. Such rights in turn stress the

67 Maslova and Nalbandovv Russia, ECtHR, 839/02, 24 January 2008.

68 Bouyidv Belgium, para. 106.

69 McKayv the United Kingdom, ECtHR, 543/03, 3 October 2006, para. 30; Medvedev and others $v$ France, ECtHR, 3394/03, 29 March 2010, para. 76; Ladent v Poland, ECtHR, 11036/03, 18 March 2008, para. 45. Ashworth and Redmayne, Criminal Process, at 38.

70 For a cautionary note on the use of operational independence to shield police policy from scrutiny, see A. Malik, Democracy and epistocracy reconciled? The Scottish Police Authority and police governance in Scotland after 2012, 2017, PhD Thesis, University of Edinburgh, pp. $35^{-37}$.

71 P.F. and E.F. $v$ The United Kingdom, ECtHR, 28326/og, Decision on Admissibility, 23 November 2010, para. 41; S., V. and A. $v$ Denmark, ECtHR, 35553/12, 36678/12, 36711/12, 22 October 2018, para. 123. On police control of privileged information and the limits of democratic policing, see Harkin, 'Simmel, the police form and the limits of democratic policing'.

72 Austin and others $v$ The United Kingdom, ECtHR, 39692/09, 40713/09, 41008/o9, 15 March 2012, para. 55 . 
importance of maintaining records of detention, something lacking in a number of cases. ${ }^{73}$

As Neyroud and Beckley note, convention rights do not operate in isolation from one another. ${ }^{74}$ Article 5 can be seen operating in coordination with Article 11 rights to freedom of assembly in the Frumkin case, in which police diverted and then terminated a political rally, and arrested, with others, the applicant who was detained and convicted of an administrative violation. The Court noted both a targeted and general effect of discouraging engagement in opposition politics and carried the "serious potential to deter opposition supporters and the public at large from attending demonstrations and, more generally, from participating in open public debate". ${ }^{75}$ Where this concerns oppressive action against marginalised groups, defined by ethnicity and other characteristics, the reinforcement of marginalisation is a key concern for the inclusion of diverse groups in a safe and secure public sphere. ${ }^{76}$

\section{$6 \quad$ Policing for Democracy 3: Political Rights (Articles 8 through 11 and Protocol 1.3)}

The rights concerned above are fundamental, in that without life or physical safety, provided equitably and effectively across society, the free and equal enjoyment of political rights necessary to democracy is similarly absent. Those

73 Anguelova v Bulgaria, ECtHR, 38361/97, 13 June 2002, para. 157; Menesheva v Russia, paras 87 and 15o. The 'unacknowledged and incommunicado' detention of Khaled El Masri in Skopje, with no custody records and no court authorisation, prior to his transfer to CIA agents and removal to Afghanistan is perhaps one of the most egregious examples of an article 5 breach. El-Masriv "The Former Yugoslav Republic of Macedonia", ECtHR, 39630/o9, 12 December 2012, particularly para. 237.

74 Neyroud and Beckley, Policing, Ethics and Human Rights, p. 63.

75 Frumkin v Russia, ECtHR, 74568/12, 5 January 2016, para. 141.

${ }_{7} 6$ We also reviewed Article 7, concerning the principle of no punishment without law. The focus is on restricting findings of guilt and sentences of punishment only to those acts clearly defined in criminal law. This suggests, first and foremost, a focus on the criminal courts, their procedures and decisions. Nonetheless, as Harkin has set out, the police routinely deploy force in ways which deliver pain and which can be analysed in terms of punishment and punitiveness. Particularly, he identifies deprivation of liberty, of security and of autonomy as key pains delivered by police, whether 'virtuously, justifiable, accidentally, malicious or otherwise'. Notably these are matters covered by other articles, and so our review of Article 7 does not highlight significant cases dealing directly with police action. D. Harkin 'The Police and Punishment: Understanding the Pains of Policing', Theoretical Criminology, 2015, vol. 19, no. 1, pp. 43-58, particularly 44-47. DoI: 10.1177/ 1362480614543043 . 
political rights are further protected from direct state infringement by Articles 8 through 11. Their connection to democracy is strong, is reflected in Court decisions, and where some infringements are accepted they are evaluated in terms of necessity in a democratic society. ${ }^{77}$ Each article is discussed in turn below. Protocol 1.3 protects free elections, but there is limited case law specifically concerning police. Harassment of election observers in Azerbaijan gives a clear example of policing contrary to the right and against democracy, but requires little further comment. ${ }^{78}$

\subsection{Article 8: Privacy}

Article 8 protects a number of important features in a democracy including the right to private correspondence and a wider principle of individual autonomy and self-realization. The limiting of state oversight is linked to the freeflow of ideas between individuals, an awareness of the risk of self-policing, and of meaningful participation in democracy being reliant on having a space "separate from the pressures and conformities of collective life". ${ }^{79}$ Two Russian cases examine state oversight of individuals' private lives, and how far, when it amounts to interference, this is subject to judicial scrutiny (a point we return to on responsiveness, below). Both cases concern human rights activists. In Shimovolos, the key conclusion leading to the finding of violation of Article 8 is the basis of law in secret ministerial orders, and absence of public knowledge or opportunity for scrutiny. This in turn opens up the data collected to abuse, in this case to police obstruction of the individuals' ability to pursue their activities in the public sphere. ${ }^{80}$ The Zakharov case handles an equally inscrutable and even wider surveillance scheme, and the applicant submits concerns about the anti-democratic possibilities of state data-collection. In this case, it is the opportunity for officers to accept bribes from politicians to unlawfully intercept rivals' communications, thus undermining an open and fair democratic process. ${ }^{81}$ The Court was satisfied that rules governing the storage of and access to material collected through secret surveillance were sufficient to

77 Ashworth and Redmayne, Criminal Process, at 37 and 43 .

78 Namat Aliyevv Azerbaijan, ECtHR, 8705/o6, 8 April 2010. Notably here, the Court focuses less on the facts and more on the failure of the subsequent processes to adequately address the applicant's arguable claim of interference.

B.J. Goold, 'How much surveillance is too much? Some thoughts on surveillance, democracy and the political value of privacy', in D.W. Schartum (ed.) Overvåkning i en Rettstatt Surveillance in a Constitutional Government, 2010, Bergen: Fagbokforlaget, pp. 38-48, at $42-44$.

8o Shimovolos $v$ Russia, ECtHR, 30194/o9, 28 November 2011, para. 69.

81 Roman Zakharovv Russia, ECtHR, 47143/o6, 4 December 2015, paras 253, 302-305. 
minimise risks in this area but that overall the arrangements and practices regarding supervision of the procedures were not sufficiently effective. ${ }^{82}$

As with other rights, Article 8 creates positive obligations on the state. These are evident in cases where threats to an individual based on aspects of their identity fall short of Article 3 violations, as seen in police and prosecution failures to investigate threats against Roma villagers during a series of far-right marches. ${ }^{83}$ The Court defines private life broadly in terms of a personal autonomy embracing "multiple aspects of a person's physical and social identity". ${ }^{84}$ This can be linked to statements elsewhere about the value of pluralism, and with points above on the communicative aspect of police action and inaction. The Court stresses the impact of negative stereotyping in terms of individuals' sense of identity, self-worth and self-confidence ${ }^{85}$ which informs their sense of their place in society. In the instant case, the Court noted the context of a pattern of violence and intolerance, generating an additional positive obligation on the state to respond. ${ }^{86}$

\subsection{Article 9: Freedom of Conscience}

Article 9, concerning freedom of conscience raises issues of the positive obligation on police to protect equitably the convention rights. In the Gldani Congregation case, in placing freedom of religion as a foundational aspect of democracy, the Court identifies "public order, religious harmony and tolerance" as a key aspect of a democratic society. ${ }^{87}$ Here, the obligation is placed on the state to protect the free exercise of religious practice. In Gldani Jehovah's Witnesses were attacked in their meeting place. Members of the congregation cited numerous examples of appeals to police that were met with passive responses, outright refusals to intervene or statements indicating sympathy with the attackers. ${ }^{88}$ The leader of the attack stated publicly that he alerted police to any forthcoming attacks to secure their non-intervention, and this was

$82 \quad$ Ibid, para. 253 .

83 R.B. v Hungary, ECtHR, 646o2/12, 12 April 2016.

84 Ibid, para. 78. In a dissenting opinion, Judge Wojtyczek rejects this interpretation, rather seeking to limit the concept of private life in ways which bring it closer to a concept of "autonomy and secrecy in personal matters", suggesting that this would not include ethnic identity which is protected under other articles (particularly 3 and 14) and other international instruments.

85 Ibid.

$86 \quad$ Ibid, para. 84 .

8797 Members of the Gldani Congregation of Jehovah's Witnesses and 4 Others $v$ Georgia, ECtHR 71156/01, 3 May 2007, paras 129 \& 132.

$88 \quad$ Ibid, para. 28. 
confirmed by NGOs. ${ }^{89}$ The lack of impartiality and the police refusal to act to protect the members of a minority religion clearly act as a direct threat to pluralism and to the spaces for different civic and religious groups to contribute to wider social and political life in a democratic context.

\subsection{Article 1o: Free Expression}

In Article 10 cases concerning free expression, we focus on police action against the media and its impact on the free exchange of ideas and information. Sanoma Uitgevers against the Netherlands shows a free media as serving a key function in a democracy, to be protected from undue police interference. In this case, a car magazine was pressured into handing over material regarding an illegal street race which they had gathered under conditions of anonymity as part of an article on the phenomenon. ${ }^{90}$ The case hinged upon police and prosecutorial summonses to surrender photographic material. Only after the temporary arrest of a journalist, the threat of sealing and searching the company's premises and removing all computers, and receiving the view (not legally binding) of an investigating judge, did the company's lawyer hand over a CD of photographs. ${ }^{91}$ The Court identifies freedom of expression as an essential foundation of a democratic society, key to societal progress and individual self-fulfilment. With specific reference to the press, it cites their role as a public watchdog and within this the importance of the freedom to receive and impart information and ideas without improper state interference. ${ }^{92}$ In the case under consideration the Court deemed the credible threat to seal and search offices, with an implication on the production and circulation of time sensitive news, an improper interference and, we can infer, anti-democratic. ${ }^{93}$ The implications go beyond the specific case in raising the prospect of a broader 'chilling effect' on the operation of a free media in relation to anonymous sources. ${ }^{94}$

A further case shows a combination of active interference and failures to protect with regard to the Özgür Gündem newspaper. As identified in relation to Article 2 and Article 3 cases above, the state was aware of violent acts being directed at those associated with the newspaper, including sellers, journalists and other staff. Their failure to act falls short of positive obligations under

\footnotetext{
$89 \quad$ Ibid, para. 36.

9o Sanoma Uitgevers B.V. $v$ The Netherlands, ECtHR 38224/03, 14 September 2010.

$91 \quad$ Ibid, paras $15^{-22 .}$

$92 \quad$ Ibid, para. 50.

93 Ibid, para. 70.

$94 \quad$ Ibid, para. 71.
} 
Article 10 as well as Article 2 and Article $3 .{ }^{95}$ In this case, inaction was compounded by further state actions, namely disproportionate and unjustified seizures of the newspaper's documents, archives and library and a mass arrest of all present at the newspaper's offices, interfering with production and dissemination of the news. ${ }^{96}$ In the context of a publication antagonistic to state aims and policy, the Court reiterates the importance of the press in meeting a public right to "information and ideas on political issues, even divisive ones" and that this kind of communication is central to the public "discovering and forming an opinion of the ideas and attitudes of political leaders". ${ }^{97}$

\subsection{Article 11: Freedom of Assembly and Association}

Public and private assembly is a key means by which citizens communicate with each other and with governing authorities. The case of Steel and Others $v$ the United Kingdom covers Articles 10 and 11, as it concerns freedom of expression in the context of public assembly. ${ }^{98}$ The case examines three separate instances of protest and police intervention: the protest against a grouse shoot (Steel), against a motorway extension (Lush), and against arms sales (Needham, Polden and Cole). In each, applicants had been detained. The case shows the difference between lawful and legitimate interference with the rights, in the case of the first two applicants where the Court found arrest and detention proportionate to risks of physical injury and breach of the peace, and unlawful interference absent grounds to infer such risks from the peaceful leafleting by the three others..$^{99}$ Remaining Article 11 cases of interest raise matters of securing safe demonstrations, and of necessity and proportionality when police close down public demonstrations, particularly spontaneous demonstrations taking place in a wider context of legal or administrative restrictions.

The Court recognises the fact that political demonstrations respond to events and so decisions to block them require effective and timely means for challenge. ${ }^{100}$ Further, even where the demonstrations are not authorised, the Court requires a degree of tolerance on the part of the police. This is evident when contrasting Eva Molnár's application against Hungary with the case of Bukta $v$ Hungary and three Turkish cases. ${ }^{101}$ In Molnár, unauthorised protests

\footnotetext{
95 Özgür Gündem v Turkey, ECtHR, 23144/93, 16 March 200o, paras 43-46.

$96 \quad$ Ibid, para. 49 .

$97 \quad$ Ibid, para. 58 .

98 Steel and Others $v$ the United Kingdom, ECtHR, 24838/94, 23 September 1998.

99 Ibid, paras 64, 104, 109 and 110.

100 Patyiv Hungary, ECtHR, 35127/08, 17 January 2012, para. 23.

101 Molnárv Hungary, ECtHR, 10346/05, 7 October 2008; Bukta and Others v Hungary, ECtHR, 25691/04, 17 July 2007; Aldemir and Others v Turkey, ECtHR, 32124/o2, 18 December 2007;
} 
against the electoral authorities blocked traffic in central Budapest. ${ }^{102}$ The crowds, which had gathered in the early afternoon, were not dispersed until 9 pm and the Court found that police had shown the "necessary tolerance", giving protestors an acceptable period to exercise their rights before intervening to end disruption. ${ }^{103}$ In Bukta, protestors gathered before a hotel in response to the Prime Minister's attendance at a commemorative event, made public just the day before. The demonstrators gave no notification of their intention to gather. ${ }^{104}$ Upon hearing a loud noise, the police decided to move demonstrators away on security grounds. A domestic court found this lawful as demonstrators had not given the required three days' notice. ${ }^{105}$ Given this was a peaceful protest with only minor disturbance, ECtHR found the police fell short of the tolerance required. ${ }^{106}$ Similarly in Balcık, the Court was "struck by the authorities' impatience" in bringing a demonstration to a close and the disproportionate nature of the intervention involving tear gas and truncheons. ${ }^{107}$ Similar concerns are expressed in Oya Ataman ${ }^{108}$ and Aldemir, ${ }^{109}$ with the explicit concern of the Court that such actions have a chilling effect on further demonstrations. ${ }^{110}$ The Court in Oya Ataman further notes the possibility of positive obligations to protect the effective enjoyment of the right to assembly. ${ }^{111}$ The Court had earlier resisted developing a 'general theory' of positive obligations arising from Article 11, but is clear that demonstrators must be able to proceed without fear of violence from opponents. ${ }^{112}$

To conclude this section, it is evident that the convention rights call on police to act in ways which do not damage and which protect wider democracy and the role of individuals and institutions in that democracy, and so we can observe a close overlap between human rights and policing for democracy. In numerous cases the police have failed to meet their obligations effectively or

Balck v Turkey, ECtHR, 63878/oo, 26 April 2005; Oya Ataman v Turkey, ECtHR, 74552/o1, 5 December 2006.

102 Molnárv Hungary, para. 10.

103 Ibid, para 43-44. Similarly, after a period of 2 months of peaceful occupation and hungerstrikes in a Church, the Court judged that police intervention was reasonable and that the protesters' "presence had been tolerated sufficiently long enough". Cisse $v$ France, ECtHR, 51346/99, 9 April 2002, para. 52.

104 Buktav Hungary, paras 8-9.

105 Ibid, paras 10, 34.

106 Ibid, para. 37.

107 Balcı $v$ Turkey, paras 51, 53 .

108 Oya Ataman $v$ Turkey, paras 41, 43.

109 Aldemir and Others $v$ Turkey, paras $46-47$.

110 Ibid, para. 34.

111 Oya Ataman v Turkey, para. 50.

112 Plattform “Ärzte fur das Leben" v Austria, ECtHR, 10126/82, 21 June 1988, paras 31-32. 
equitably, particularly in relation to groups that are marginalised or disadvantaged, whether on grounds of ethnic identity, religion or gender. Further, both failure to act and more active breaches of rights show anti-democratic elements of policing where political and civil society sources of opposition to governments are blocked in their efforts to challenge or hold to account the government of the day, a key aspect of democracy. The issue of accountability is one which can be transposed from the wider functions of government to the specific governance arrangements for the police. In the section that follows, we explore the case law of the Court through the lens of democratically responsive policing - that is policing which does not simply support political democracy, but which is governed, organised and implemented in a way which is itself democratic, understood in terms of responsiveness.

\section{$7 \quad$ Responsiveness and Convention Rights}

As noted above, democratically responsive policing is characterised by a master concept of responsiveness, itself divided into horizontal and vertical forms. The following analysis comes in two sections. The first handles mechanisms for vertical responsiveness, in which the police respond directly to the public. The second examines instances where rights require a response to other institutions. As reaction and accessibility, measures of police responsiveness to individual calls for service, are about protecting individuals, there is some overlap between the articles cited in the previous sections and here, particularly Article 2 and 3. Beyond this, principles of distribution of power, access to information, accountability and redress bring in Articles 5, 6, 10 and 13. As we move from assessing police action to wider frameworks underpinning that, the value of a wider concept of a democratically responsive police system is clear.

\subsection{Vertical Responsiveness: Citizens and Service Users}

Vertical responsiveness means citizens have mechanisms to indicate their interests to authorities and those authorities are required to respond in a meaningful way. In this section we show the Court is attentive to citizens' calls for service, in terms of accessibility and reaction, and through mechanisms for redress. ${ }^{113}$ Earlier we examined threats from the state and state failures to protect individuals from a known threat. This overlaps with a vertical response

113 See Aitchison and Blaustein, 'Policing for Democracy or Democratically Responsive Policing?' p. 501. 
when members of the public call for preventive or protective police action. The $O p u z$ case demonstrated the state's failure to protect the physical safety of the applicant and the life of her mother. In relation to vertical responsiveness, the authorities consistently failed to read the applicant's interests from her pattern of behaviour and from knowledge of domestic abuse. The government relied in part on the applicant's repeated withdrawal of complaints to defend their lack of investigative and prosecutorial action, ${ }^{114}$ yet the Court found the authorities showed no effort to understand her motives. The interest indicated by the applicant's initial call for help still necessitated action notwithstanding subsequent contradictory indicators. It requires a positive response, pursuing the initial complaint, and a negative response with reason, continuing after withdrawal of a complaint in light of other information about the specific situation and the general category in which it is located (domestic violence). The Court favours legal frameworks that allow continued investigation and prosecution despite the withdrawal of a complaint. ${ }^{115} \mathrm{Opuz}$ and the wider issue of domestic violence highlight the limits of a reactive court and police service in terms of which citizens' interests they can access and respond to. The Court notes that while domestic violence is a general problem in all member states, it "does not always surface", remaining hidden in private spaces and personal relationships. ${ }^{116}$ People do not necessarily make even an initial call for help, and particular subgroups face obstacles to help-seeking. ${ }^{117}$ Both Mirza's interviews and Opuz suggest that while the interest of an individual in life and security is so fundamental, and state and police authorities need no special mechanism to know this, threats to those interests can remain unknown to police for structural reasons, or when they are known, may not be given due priority. ${ }^{118}$

Individuals also communicate their interests in an investigative response after the event of the death of another or of serious injury. The police response to deaths, outside the bulk of those occurring under medical supervision, is normally to launch an investigation, ${ }^{119}$ so what is at issue for the Court is the

\footnotetext{
114 Opuzv Turkey, para. 123.

115 Ibid, paras 143 and 168.

116 Ibid, para 132.

117 For example, see N. Mirza, 'South Asian Women's Experience of Family Abuse: Examining the Police Response' SIPR Research Summaries, No. 21, pp. 4-5. http://www.sipr.ac.uk/ Plugin/Publications/assets/files/Research_Summary_21.pdf.

118 See also Kontrová v Slovakia, ECtHR, 7510/04, 31 May 2007.

119 Notification of a death gives rise to an obligation to investigate, although that investigation need not take the form of a criminal investigation, Emars $v$ Latvia, ECtHR, 22412/o8, 18 November 2014, paras 74, 77. Further in cases of suspected medical negligence, criminal investigations may be instigated at the request of next-of-kin, as seen in Byrzykowski $v$ Poland, ECtHR, 11562/05, 27 June 2006, para. 108.
} 
adequacy of that investigative response. ${ }^{120}$ In relation to vertical responsiveness, the Court has emphasised the necessity in all cases following loss of life, to directly involve the victim's next-of-kin "to the extent necessary to safeguard his or her legitimate interests". ${ }^{121}$ Further, the provision of information is a key element of responsiveness, ${ }^{122}$ whether as a response to citizens or as a means to allow citizens to identify their needs and interests and signal these to the police. Failings in investigations, including in giving clear information to victims or their next of kin regularly occur and can amount not just to a failing under our heading of response, but can be grounds for a breach of Article 3 due to the suffering of those left excluded from an investigation. ${ }^{123}$

Redress ${ }^{124}$ includes another vertical response, particularly the possibility for citizens to challenge unfair treatment, or to have wrongs investigated and, where appropriate, properly compensated. ${ }^{125}$ The individual calls for their interest to be recognised and this can influence subsequent police behaviour. We see this in Article 5.5 (compensation for detention in breach of right to liberty), Article 6 (entitlement to fair and public hearing) and Article 13 (right to effective remedy for violation of treaty rights). Many Article 5.5 cases arise from situations where the relevant aspects of the convention have not been fully incorporated into domestic law and so do not figure in legal reasoning and decision making in domestic courts. Applicants had been unable to have a complaint and claim for compensation examined nationally, as there had been no determination at the national level that detention was unlawful. ${ }^{126}$ Regarding Article 6 and 13, the related issues are often taken together under

120 Examples of inadequate investigation including failure to secure key evidence or to follow central lines of questioning can be seen in Muliniv Bulgaria, ECtHR, 2092/08, 20 October 2015, paras 46-47.

121 Emars $v$ Latvia, para. 74.

122 Notably, we are extending beyond and individualising the principle of information outlined by Jones, Newburn and Smith, Democracy and Policing, pp. 47-48.

123 Luluyev and Others $v$ Russia, ECtHR, 69480/o1, 9 November 2006, para 117. In other cases, this goes further, to include the provision of false information to next-of-kin. See Timurtaş v Turkey, ECtHR, 23531/94, 13 June 2006, para. 97.

124 T. Jones, T. Newburn and D. Smith, 'Policing and the Idea of Democracy', British Journal of Criminology, 1996, vol. 36, no. 2, pp. 192-198. Dor: 10.1093/oxfordjournals.bjc.a014081.

125 Ibid, p. 192.

126 Rehbock v Slovenia, paras. 91-92; Yankov v Bulgaria, ECtHR, 39084/97, 11 December 2003, paras. 194-196; Sakık and others $v$ Turkey, ECtHR, 23878/94, 23879/94, 2388o/94, 23881/94, 23882/94, 23883/94, 26 November 1997, para. 52; Harkmann $v$ Estonia, ECtHR, 2192/03, 11 July 2006, para. 52; Brogan and others $v$ the United Kingdom, ECtHR, 11209/84, 11234/84, 11266/84, 11386/85, 29 November 1988, para. 67; Nolan and Kv Russia, ECtHR, 2512/04, 6 July 2009, para. 104. 
Article 13, which is seen to be the broader of the two. ${ }^{127}$ A number of cases show how a lack of initial investigation by the police or related authorities into evident police misconduct has obstructed a remedy, either because there was no feasible alternative for a complainant to evidence their claim, or because remedies depended on outcomes in criminal processes. ${ }^{128}$ For example, Egemezv Cyprus illustrates the necessity of state support when prosecution is the means of remedying police misconduct. The government claimed that private prosecution was a credible avenue for the complainant to pursue redress, but could offer no evidence of successful private prosecutions of police torture. Absent backing for prosecution from the Attorney General, the Court was not convinced this was an effective route to remedy. ${ }^{129}$

A number of UK cases highlight key features of systems of redress around issues of immunity, balance and independence. In Osman, the Court examines UK precedent which claimed to protect wider community interests in effective policing by preventing the police from being constantly exposed to the risk of "tortious liability for policy and operational decisions". ${ }^{130}$ In the Court's view, this amounts to blanket immunity, and obstructed the right of the applicants to have their claim of police negligence examined. ${ }^{131}$ In Keegan, the concern was not a blanket immunity but a requirement that the applicants would have to prove not simply police negligence in a wrongly targeted raid, rather malice. Setting the balance thus did not reflect the breach of Article 8 rights and the need for an effective mechanism of redress. ${ }^{132}$ Finally, Khan presents limitations to the then system for police complaints in England and Wales, showing a lack of clarity on the Police Complaints Authority's power over and oversight of Chief Constables, and in its insufficiently independent relationship towards the executive in terms of appointments and funding. ${ }^{133}$

127 Menteş $v$ Turkey, ECtHR, 23186/94, 28 November 1997, para. 8; Giuliani and Gaggio v Italy, ECtHR, 23458/02, 24 March 2011, para. 335.

128 Salman $v$ Turkey, ECtHR, 21986/93, 27 June 2000, paras 121-123, along with Menteş, provides an example of one of multiple similar Turkish cases; similar issues arise in El Masri v FYR Macedonia, Menesheva $v$ Russia and Tsonchev v Bulgaria, ECtHR, 41488/98, 18 May 2000. These can be contrasted to cases where remedies were not dependent on findings arising from criminal procedure, e.g. McKerr $v$ the United Kingdom, ECtHR, 28883/95, 4 May 2001; Giuliani and Gaggio $v$ Italy.

129 Egemez $v$ Turkey, ECtHR, 30873, 21 December 2000.

130 Osman $v U K$, para. 149 .

131 Ibid, para. 150.

132 Keegan $v$ the United Kingdom, ECtHR, 28867/03, 18 July 2006, para. 42.

133 Khan $v$ the United Kingdom, ECtHR, 35394/97, 12 May 2000, paras 45-47; reiterated in P.G. and J.H. $v$ the United Kingdom, ECtHR, 44787/98, 25 September 2001. 
Finally, building on Loader and Walker's discussion of recognition, ${ }^{134}$ the mechanisms of redress outlined here go beyond citizens to provide a means by which non-citizens are included in processes of contestation regarding processes and actions affecting them. ${ }^{135}$ Recognition, as a principle of civilized security calls for inclusive mechanisms that give voice to 'the interests and ideas of those who can reasonably claim a stake in the outcome' of a state's decisions and actions. ${ }^{136}$ Non-citizens excluded from democratic participation in other fora nonetheless have an entitlement to systems of remedy, redress and compensation as a feedback mechanism.

That said, concerns have been raised about the impact of the Court acting as a venue for individual claims of redress, and as an adjudicator of claims that could have been settled within states with proper integration of the convention into domestic law, on the capacity of the Court to fill a wider role of constitutional adjudication and harmonisation at or above a set of minimum standards of rights protection. ${ }^{137}$ This is not to say the Court has no role in ensuring redress, rather that this purpose may be better served by the Court's wider governance role in supervising states' own systems of redress rather than by direct delivery of redress through judgments.

\subsection{Horizontal Responsiveness: Landscapes of Governance}

Finally, we examine the Court's role in a horizontal democratic plurarchy, where multiple bodies are arranged in a landscape of governance to best represent and balance citizens' interests. The totality of the cases already presented suggests the ECtHR fits such a framework as police authorities are repeatedly critiqued and states sanctioned for infringing rights, failing to protect individuals and acting in ways that are inattentive, or detrimental, to equity. Yet Kuper is clear that the requirements of horizontal responsiveness go well beyond a strong judicial check. He suggests that the judiciary are limited by the legal form, jurisprudential logic and distance from political engagement that is a condition of their autonomy. ${ }^{138}$ Courts are not active seekers of complaints, do not educate the public on their rights, nor do they compensate for weak

\footnotetext{
134 Loader and Walker, Civilizing Security, pp. $220 \mathrm{ff}$.

135 See e.g. M.S.S. $v$ Belgium and Greece, ECtHR, 30696/og, 21 January 2011 and El Masriv FYR Macedonia, dealing respectively with Afghan and a German citizens.

136 Loader and Walker, p. 220.

137 S. Greer, 'What's wrong with the European Convention on Human Rights', Human Rights Quarterly, 2008, vol. 30, no. 3, pp. 680-702, at 680, 684 and 692; de Londras, 'Dual functionality' at $42-43$.

138 Ibid, p. 109.
} 
civil society institutions as substitute advocates of policy change. ${ }^{139}$ In short, courts' operating conditions are not geared towards compromise and consensus and they are reactive rather than proactive. Against these limitations, there are two ways in which the Court could function as part of a system of horizontal responsiveness. First, by exploring the margin of appreciation allowed by ECHR, we might question the suggested judicial rigidity that Kuper sees as an obstacle to consensus and compromise. Second, we present Court judgments in support of other institutions in a landscape of governance and favouring principles of accountability, distribution of power and information.

The margin of appreciation is a means to balance national constitutional values with the universality of human rights, but applies to how and in what circumstances states can limit rights, rather than the actual substance of the rights. It links Kuper's epistemic framing in that national authorities are viewed as "best placed to assess the necessity and appropriateness of restrictions and limitations". ${ }^{140}$ That is, the executive's particular political knowledge is given due weighting. While Gerards has concerns about inconsistent specification and reasoning when the Court applies the margin, she still favours other ways in which the Court handles divisive matters by a gradual approach, with a strong emphasis on the individual facts in a case. ${ }^{141}$ Young, in a different context, argues that appropriate deference from courts to legislatures and executives is about the recognition of expertise, knowledge and access to evidence in those branches. ${ }^{142}$ As such, the rigidity perceived by Kuper is reduced in the specific case of ECtHR, and recognition of other authorities' alternative sources and modes of knowledge triggers the Court's mechanisms of compromise and consensus.

In several cases, the judgment and reasoning of the ECtHR offers support to, or is suggestive of standards of effectiveness in domestic institutions, but often these are courts and would face the limitations as part of a framework of horizontal responsiveness outlined by Kuper. In Gutsanovi, the Court notes that prior judicial review of a police operation would have allowed for a proper weighing of legitimate interests of those affected against the public interest in arrest. ${ }^{143}$ In Delta and Palaoro respectively, the domestic courts are a necessary

\footnotetext{
139 Ibid.

140 J. Gerards, 'Margin of Appreciation and Incrementalism in the Case Law of the European Court of Human Rights', in Human Rights Law Review, 2018, vol. 18, no. 3, pp. 495-515, at pp. 496 and 498. DOI: 10.1093./hrlr/ngyo17.

141 Ibid, pp. 508, 512.

142 A. Young. 'In Defence of Due Deference', in Modern Law Review, 2009, vol. 72, no. 4, pp. 554-580, at pp. 555 and 570 .

143 Gutsanoviv Bulgaria, para. 133.
} 
venue to test knowledge generated in police investigations and the technology used by police. ${ }^{144}$ In Zakharov, we saw how Article 8 was breached by the lack of an effective and proactive judiciary, or alternative independent supervisory arrangements, providing oversight of covert surveillance. This is especially true given the lack of possibility for an individual to challenge the, generally secret, measures themselves. Collectively, the cases emphasise the value of independent checks and kinds of evidence and reasoning that courts provide, suggesting the value of alternative epistemic frameworks. ${ }^{145}$

In different ways, the ECtHR supports other institutions with a less formal, but nonetheless important, role in the landscape of police governance. Article 10 cases reviewed earlier stress the role of the press in a wider political democracy. Further cases involve the freedom of the press to act as a check on police misconduct. ${ }^{146}$ Finally, the ECtHR is a venue in which NGOs and other groups can voice their concerns in relation to the interests of sections of society of whom they have specific knowledge. A review of cases up to 2013 shows 142 NGOs providing 294 briefs across 237 cases under provisions in Article 44.3(a) of the ECtHR rules. ${ }^{147}$ In a number of cases, for example, the European Roma Rights Centre, Interights and the Open Society Justice Initiative have intervened in ways that provide the Court with important contextual knowledge on marginalisation and victimisation of Roma. This may push at the boundaries of the notion of a democratically responsive police system as we get further away from executive and judicial bodies, but a system can consist of multiple components, some more central than others, just as in a landscape of governance some elements may be central and others peripheral.

\section{$8 \quad$ Conclusion}

In examining the conceptual overlap between human rights and the two separate forms of democratic policing, our analysis strengthens the case for separating out these two elements. The conceptual mapping and the analysis of ECtHR have shown a strong close match between convention rights and

\footnotetext{
144 Delta v France, ECtHR, 11444/85, 19 December 1990; Palaoro v Austria, ECtHR, 16718/90, 23 October 1995.

145 Zakharov $v$ Russia, particularly paras 233, 257, 259 and 274-281.

146 Sürekv Turkey II, ECtHR, 24122/94, 8 July 1999, paras 37-39; Thorgeir Thorgeirson v Iceland, ECtHR, 13778/88, 25 June 1992; Tillackv Belgium, ECtHR, 20477/05, 27 November 2007.

147 L. van den Eynde, 'An Empirical Look at the Amicus Curaie Practice of Human Rights NGOs before the ECHR', in Netherlands Quarterly of Human Rights, 2013, vol. 31, no. 3, pp. 271-313, at 271, 278. DO110.1177/016934411303100304.
} 
the concept of policing for democracy. Particularly through Articles 2, 35 and 8 through 11, taken alongside Article 14, the Court sets out circumstances in which police action or inaction serves, or fails to serve, the wider aims and values of a democratic society, understood in terms of pluralism. As such, policing for rights and policing for democracy cover much of the same territory. With regards to democratically responsive policing, the 'fit' is less perfect. We have argued that the Court is a mechanism of response (vertically, in terms of redress, and horizontally in holding states to account), but that a wider set of institutional checks is required to fully meet Kuper's requirements. While some of his observations on the limitations of courts may be overstated, and in line with concerns stated in relation to the Court as a means of redress, it remains true that the Court is focused on individual cases rather than policy change. While states are "allowed and encouraged" to "draw broader inferences" from Court judgments, they are in no way obliged to. ${ }^{148}$ Still, the case law examined here provides valuable resources for those who seek to interrogate and analyse domestic legislation and other institutional arrangements to ensure that police actions support democratic values, and are themselves democratically governed. Future work can build on this by extending to other international settings or with more detailed examinations of specific jurisdictions.

\section{Acknowledgement}

The authors would like to thank colleagues at the University of Edinburgh School of Law, MEF University Law Faculty, Istanbul, and further afield, for comments on, and opportunities to discuss, the paper at various stages of development. We are especially grateful to the anonymous reviewer for perceptive and helpful comments and to Diarmaid Harkin, Alistair Henry, Ali Malik, Leandro Mancano, Francesca Soliman and Neil Walker. The final stages of the writing process were facilitated by an Erasmus+ teaching mobility visit.

148 Gerards, 'Margin of Appreciation', p. 506. Further, even when faced with similar patterns of state behaviour in breach of convention rights across cases, the Court is often explicit in avoiding examining that go beyond the individual case and challenge the behaviour as a more widespread state practice, e.g. Salman $v$ Turkey, para. 125. İlhan $v$ Turkey, ECtHR, 22277/93, 27 June 2000, para. 105. These concerns are also raised by de Londras, 'Dual functionality', suggesting a need for political as well as judicial action, drawing on the Committee of Ministers and wider Council of Europe framework. 